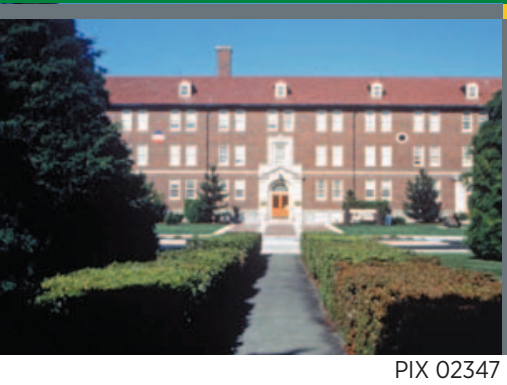

The U.S. Department of Energy's (DOE) Federal Energy Management Program (FEMP) facilitates the Federal Government's implementation of sound, cost-effective energy management and investment practices to enhance the nation's energy security and environmental stewardship.

Energy efficient lighting retrofits and appliance upgrades at the headquarters of I Corps in Ft. Lewis, Washington, are just a few of the changes made to the 4,200 buildings at the military installation through a UESC.

Utility energy services contracts (UESCs) allow Federal agencies to enter contracts with serving utilities to implement facility energy improvement projects. To fund project capital costs, agencies may arrange all financing through the utility, use Congressional appropriations, or choose a combination of both. If the project is financed through the utility, the utility is then repaid over the contract term from the energy cost savings generated by the project.

Several types of contracts are used as UESCs. Three widely used types of contracting mechanisms include areawide contracts (AWCs), basic ordering agreements (BOAs), and model agreements (also known as separate contracts). These contracts have two major components that significantly streamline the contracting process - model terms and conditions and task orders (also referred to as delivery orders).

\section{Areawide Contracts}

Areawide contracts are blanket contracts, which are essentially indefinite-delivery, indefinite-quantity (IDIQ) contracts for public utility services. It outlines general terms and conditions and authorizes any agency in the utility's service territory to place task orders for services offered under the contract. The General Services Administration (GSA) established more than 150 utility AWCs to procure utility services for Federal facilities around the country. The general process flow of an AWC includes:

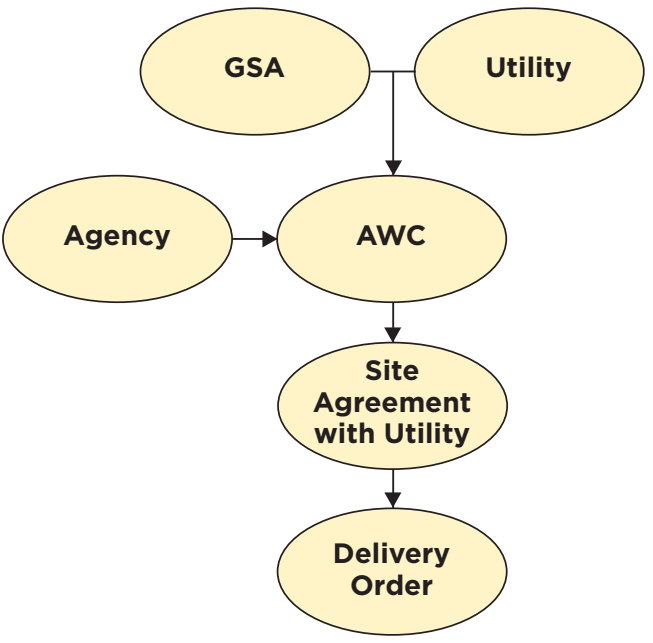

\section{Basic Ordering Agreements}

Basic ordering agreements are not contracts. However, BOAs do establish general terms and conditions for future contracts. A delivery order placed under a BOA constitutes the contract and details the services to be delivered. Any Federal agency can establish a basic ordering agreement with their utility. Department of Defense (DOD) organizations often use BOAs. The general process flow of a $\mathrm{BOA}$ includes:

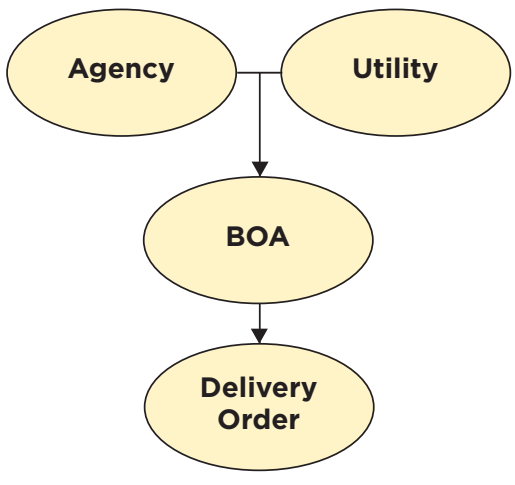

\section{Strategies to Lower Finance Costs}

1. Time is money; don't delay

2. Learn about financing

3. Use standard terms and conditions

4. Negotiate a prepayment formula

5. Include assignment of claims

6. Ask for appropriate performance verification

7. Don't buy a rate lock

8. Bundle energy conservation measures

9. Choose annual payments instead of monthly

10. Compare rates

For more information on financing negotiations and lowering rates, visit:

http://www.eere.energy.gov/femp/pdfs/uescs_lessons_ learned.pdf 


\section{Model Agreements}

Model utility service agreements for civilian and DOD agencies were developed by a collaboration of FEMP, the Edison Electric Institute (EEI), Federal technical and contracting experts, and utility partners. The agreements serve as a template for agencies to use in establishing their own UESCs or as master agreements within an AWC. Based on successful BOAs and other contracting vehicles, model agreements contain approved, required clauses for Federal contracts and are the most comprehensive compilation of contractual language for UESCs available. Model agreement clauses can be added to an AWC or a BOA. The general process flow of a model agreement includes:

\section{Performance Assurance Plans}

Because UESCs are not required to include measurement and verification or to guarantee savings, it is recommended that each financed UESC have a performance assurance plan in place for each energy conservation measure with regard to technical complexity, potential savings magnitude, and specific conditions. Agencies are granted the flexibility to pay for only the level of desired performance verification, weighing the appropriate costs versus the level of certainty of cost savings that the customer agency feels is necessary.

The minimal performance assurance plan recommended by FEMP for financed UESC energy conservation measures includes:

- Start-up performance verification (based on measured data)

- Performance verification at the end of the warranty period (based on measured data)

- Operations and maintenance training (required when the agency continues to operate and maintain installed equipment)

- Provision of continuing training throughout the contract period as specified in the contract as determined by the needs of the facility

- Periodic inspections and verification of appropriate operations and measurement performance

- Performance discrepancy resolution

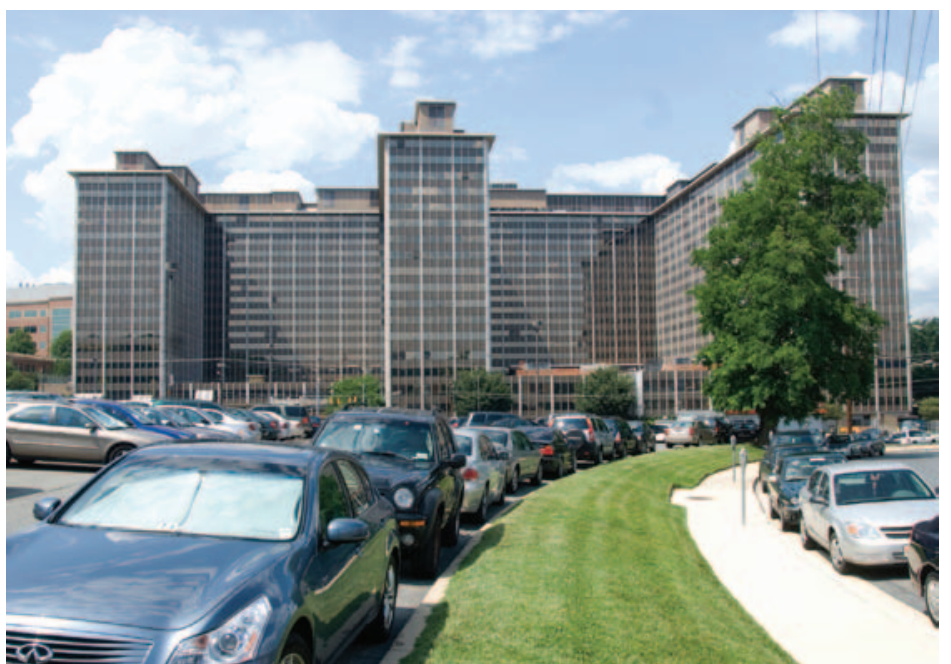

PIX 16417

Thanks to a UESC, more than 2 million kilowatt-hours and 6.3 million gallons of water are saved annually due to energy-efficient lighting upgrades and water-efficient fixtures within the Department of Health and Human Services' Parklawn Building.

\section{Resources and Contacts}

For more information on UESCs, visit: http://www.eere. energy.gov/femp/financing/uescs.html

Or contact:

\section{David McAndrew}

UESC Project Manager

DOE-FEMP

202-586-7722

david.mcandrew@ee.doe.gov

\section{Karen Thomas}

Senior Project Leader II

National Renewable Energy

Laboratory (NREL)

202-488-2223

karen.thomas@nrel.gov
For additional information please contact:

EERE Information Center 1-877-EERE-INF (1-877-337-3463) www.eere.energy.gov/informationcenter Printed with a renewable-source ink on paper containing at least $50 \%$ wastepaper, including $10 \%$ post consumer waste.
Prepared by the National Renewable Energy Laboratory (NREL) a national laboratory of the U.S. Department of Energy Office of Energy Efficiency and Renewable Energy; NREL is operated by the Alliance for Sustainable Energy, LLC.

DOE/GO-102009-2900 • July 2009 